\title{
Taxonomic notes on halacarids (Acari) from the Skagerrak area
}

\author{
Ilse Bartsch* \\ Biologische Anstalt Helgoland; Notkestr. 31, D-W-2000 Hamburg 52, \\ Federal Republic of Germany
}

\begin{abstract}
A total of 27 halacarid species were found in sediments taken at $5-25 \mathrm{~m}$ depth off the western coast of Sweden. The four species Copidognathus magnipalpus, Actacarus obductus, Coloboceras longiusculus, and Lohmannella multisetosa are new to the fauna of the northeastern North Atlantic; taxonomic diagnoses of these species are given. Anomalohalacarus septentrionalis and Camactognathus borealis, both new species, are described.
\end{abstract}

\section{INTRODUCTION}

The Kristineberg Zoological Station, on the western coast of Sweden, has often been visited by meiobenthologists intending to study near- and offshore sediments. The first record of a halacarid species (Isobactrus levis) from the Kristineberg area is that of Sellnick (1949); the first notes on mesopsammic halacarid fauna are in Monniot (1967). In recent years, I have received several collections with halacarids taken off Kristineberg. In sublittoral sediments, a total of 27 species of marine mites were found, two are new to science, and four new to the fauna of northeastern Atlantic shores.

\section{MATERIAL}

The halacarids were collected by Dr. C. Poizat, Marseilles, and Dr. H. Kunz, Saarbrücken, off Bonden, a small island in the Skagerrak, ca $10 \mathrm{~km}$ off Kristineberg, Sweden. Of special interest are series taken in July 1982 in 5, 10, 15, 20 and $25 \mathrm{~m}$ depth (Poizat, in press). The sediment at the sampling sites is rather coarse, with large amounts of broken shells of bivalves, and $0-6 \%$ silty material $(<50 \mu \mathrm{m})$; the near-bottom salinity ranges from 23 to $33 \%$ (Poizat, in press).

Abbreviations used in the descriptions: $A D$ anterior dorsal plate; $A E$ anterior epimeral plate; ds dorsal setae on idiosoma, ds-1 first pair of dorsal setae; GA genitoanal plate; GO genital opening (foramen); GP genital plate; OC ocular plate(s); $P$ palp; P-2 2nd palpal segment; pas parambulacral setae; PD posterior dorsal plate; PE posterior epimeral plate. Legs numbered I to IV, leg segments 1 to 6, I-6 tarsus on leg I.

\footnotetext{
- Member of the Taxonomy Group at the Biologische Anstalt Helgoland 


\section{SYSTEMATICS}

Examination of sublittoral sediments taken off the western coast of Sweden resulted in the recovery of 27 halacarid species (Table 1). The majority of the species found has previously been recorded from various parts of the North Sea and the English Channel region; their diagnoses are found in Green \& MacQuitty (1987). New to the fauna of the North Sea are Coloboceras longiusculus Trouessart, Copidognathus magnipalpus

Table 1. Halacarid species taken off the island Bonden, western Sweden, Skagerrak

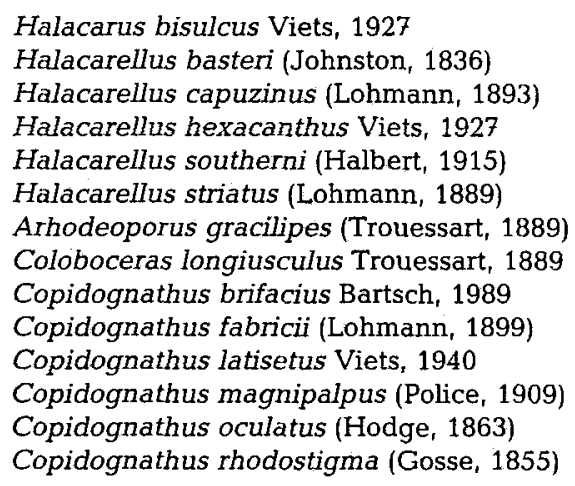

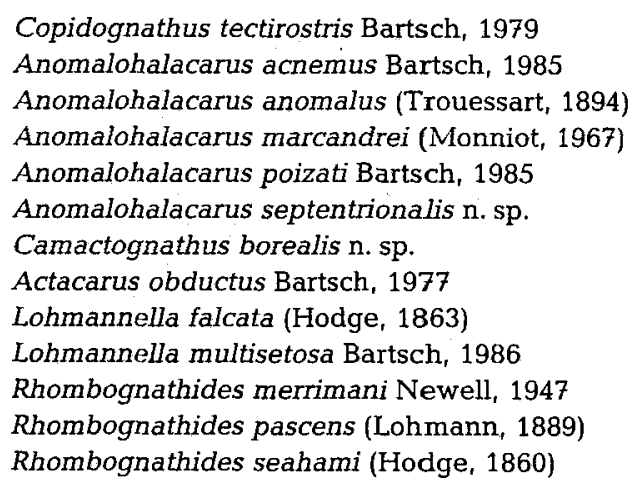

(Police), Actacarus obductus Bartsch, Lohmannella multisetosa Bartsch, Anomalohalacarus septentrionalis n. sp., and Camactognathus borealis $\mathrm{n}$. $\mathrm{sp}$. In the following, descriptions or diagnoses of Anomalohalacarus septentrionalis, Camactognathus borealis, Coloboceras longiusculus, Copidognathus magnipalpus, C. tectirostris, Actacarus obductus, and Lohmannella multisetosa are presented.

\section{Anomalohalacarus septentrionalis n. sp.}

Material: Three females, 2 males, collected off Bonden, at 15 and $20 \mathrm{~m}$ depth, July 1982, coll. C. Poizat; holotype female deposited in Zoologisches Institut und Zoologisches Museum, Hamburg.

Female: Idiosoma length 305-354 $\mu \mathrm{m}$. Length of $\mathrm{AD} 65 \mu \mathrm{m}_{i}$ anterior margin truncate, posterior margin rounded. AD with first pair of gland pore at lateral corners. OC absent. Second pair of gland pores conspicuous. PD divided into a right and left plate, with gland pores anteriorly and posteriorly. Setae ds- 1 inserted on AD, long ds-2 anterior to second pair of gland pores, rather short ds-3 placed between these gland pores, ds-4, ds-5, and short but stout ds-6 on posterior PD (Fig. 1).

Ventral plates small. AE divided by median striae of membranous integument. AE with 3 slender setae. GP divided. One pair of perigenital setae inserted within membranous integument at level of insertion of leg IV, two pairs of setae on GP. Genital groove closed (Fig. 2). Anal sclerites not protruding, flanked by the stout ds-6.

Gnathosoma length $235 \mu \mathrm{m}$. Rostrum parallel-sided, its length less than that of 

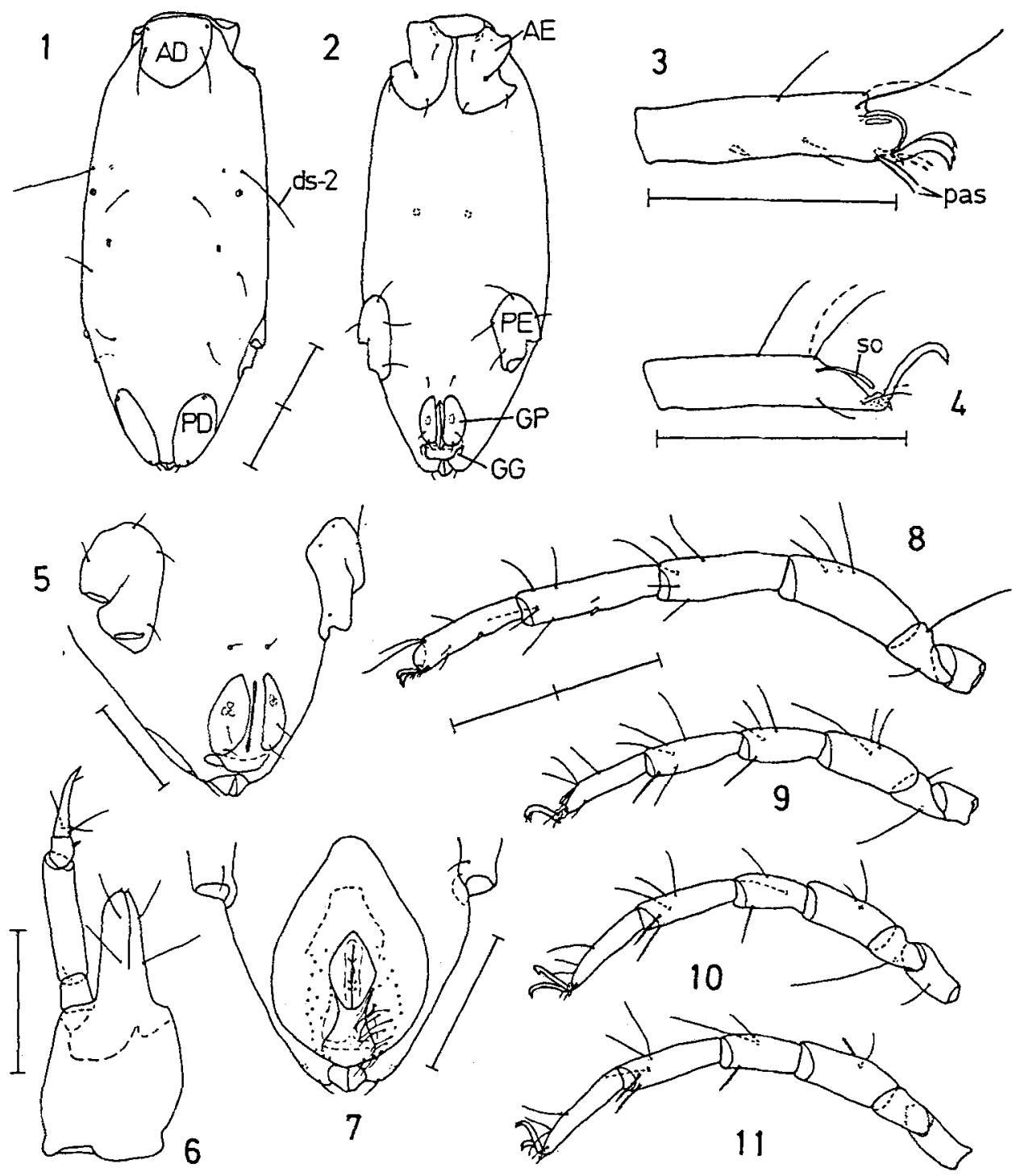

Figs 1-11. Anomalohalacarus septentrionalis n. sp. 1: idiosoma, dorsal view, female; 2: idiosoma, ventral view, female; 3 : tarsus I, lateral view (medial setae dashed), female; 4 : tarsus II, lateral view (medial setae dashed), female; 5 : posterior idiosoma, ventral view, female; 6: gnathosoma, ventral view, female; 7 : posterior idiosoma, ventral view, male; 8: leg I, medial view, female; 9: leg II, medial view, female; 10: leg III, medial view, female; 11: leg IV, medial view, female. (Each scale division represents $50 \mu \mathrm{m}$ ) (AD anterior dorsal plate; $A E$ anterior epimeral plate; ds-2 2nd dorsal seta; GG genital groove; GP genital plate; pas parambulacral setae; PD posterior dorsal plate; PE posterior epimeral plate; so solenidion) 
gnathosoma base. P-2 with a delicate basal seta (Fig. 6). P-3 with a median spinelet, P-4 with three setae in the basal whorl. Chelicerae elongate.

Leg I distinctly stronger than all other legs. In middle of tibia I, one spinelet and one minute seta present. Chaetotaxy of telofemora I-IV: $3,3,2(-3), 2$ (Figs 8-11). In one of the three females available, IV-3 with a ventrolateral bristle beside the two dorsal setae. Tarsus I with a ventral spinelet, a pair of minute ventral setae, a pair of doubled parambulacral setae, 3 dorsal setae, and a dorsolateral solenidion and famulus (Fig. 3). Tarsus II with a small ventral and 3 dorsal setae, the solenidion dorso-lateral in position, and a pair of single pas at the tip (Fig. 4). Tarsi III and IV with three dorsal setae and a pair of single parambulacral setae.

Male: Idiosoma length $297-427 \mu \mathrm{m}$. Similar to female except for the genital region. Genital plate large and fused. Large genital groove narrowed by lateral lamellae; 20-22 pairs of perigenital setae on either side of genital foramen plus groove (Fig. 7).

Remarks: The characteristics of $A$. septentrionalis are: Second pair of gland pores distinct; females with closed genital groove and the anterior perigenital setae at or posterior to level of insertion of leg IV; males with 20-22 pairs of perigenital setae; I-5 with one spinelet and one small seta in middle of segment; tarsus II with 1 ventral seta; rostrum almost surpassing middle of P-2; P-2 with one basal seta.

Species of the genus Anomalohalacarus are characteristic inhabitants of medium to coarse, sorted sediments. In the North Sea, three shallow-water and four sublittoral species are known. A. arenarius Bartsch, $A$. intermedius Bartsch, and $A$. minutus Bartsch live in intertidal and shallow subtidal sediments (Bartsch \& Schmidt, 1979), A. acnemus Bartsch, $A$. anomalus (Trouessart), $A$. marcandrei (Monniot), $A$. poizati Bartsch, and $A$. septentrionalis predominate in sublittoral sediments.

\section{Camactognathus borealis $\mathrm{n}$. $\mathrm{sp}$.}

Material: Two females, 2 deutonymphs, taken off Bonden at $15 \mathrm{~m}$ depth, July 1982 , coll. C. Poizat; holotype female deposited in Zoologisches Institut und Zoologisches Museum, Hamburg.

Female: Idiosoma length 230-237 $\mu \mathrm{m}$. Dorsal plates with irregularly shaped pits and fine porosity (Fig. 15). AD with a pair of gland pores placed just anterior to level of leg $\mathrm{I}$. OC caudiform posteriorly; no delimited corneae present; gland pore and canaliculus present at lateral margin. PD long. Dorsal setae slender; ds-1 inserted on $A D, d s-2$ at lateral margin of $\mathrm{AD}$, ds-3 on anterior margin of $\mathrm{PD}$, ds -4 , ds -5 on $\mathrm{PD}$, and ds-6 close to anal cone (Fig. 12).

Ventral plates with fine porosity. AE prolonged posteriorly, with three pairs of setae, $\mathrm{PE}$ with one dorsal and three ventral setae. Anterior margin of GA slightly excavated (Fig. 13). GO large, with three pairs of perigenital setae; genital sclerites with one pair of subgenital setae.

Gnathosoma slender. Pharyngeal plate ending midway on gnathosoma base. Rostrum longer than gnathosoma base ${ }_{i}$ rostrum base with lateral projections. Both pairs of maxillary setae inserted on rostrum. Rostral sulcus short, not extending beyond distal pair of maxillary setae (Fig. 14). Palps slender, 4-segmented, P-2 with one dorsal seta; no seta on P-3; P-4 with 3 setae in basal whorl which is removed towards end of segment's basal third (Fig. 16). Chelicerae elongate; cheliceral claw short, denticulate (Fig. 22). 

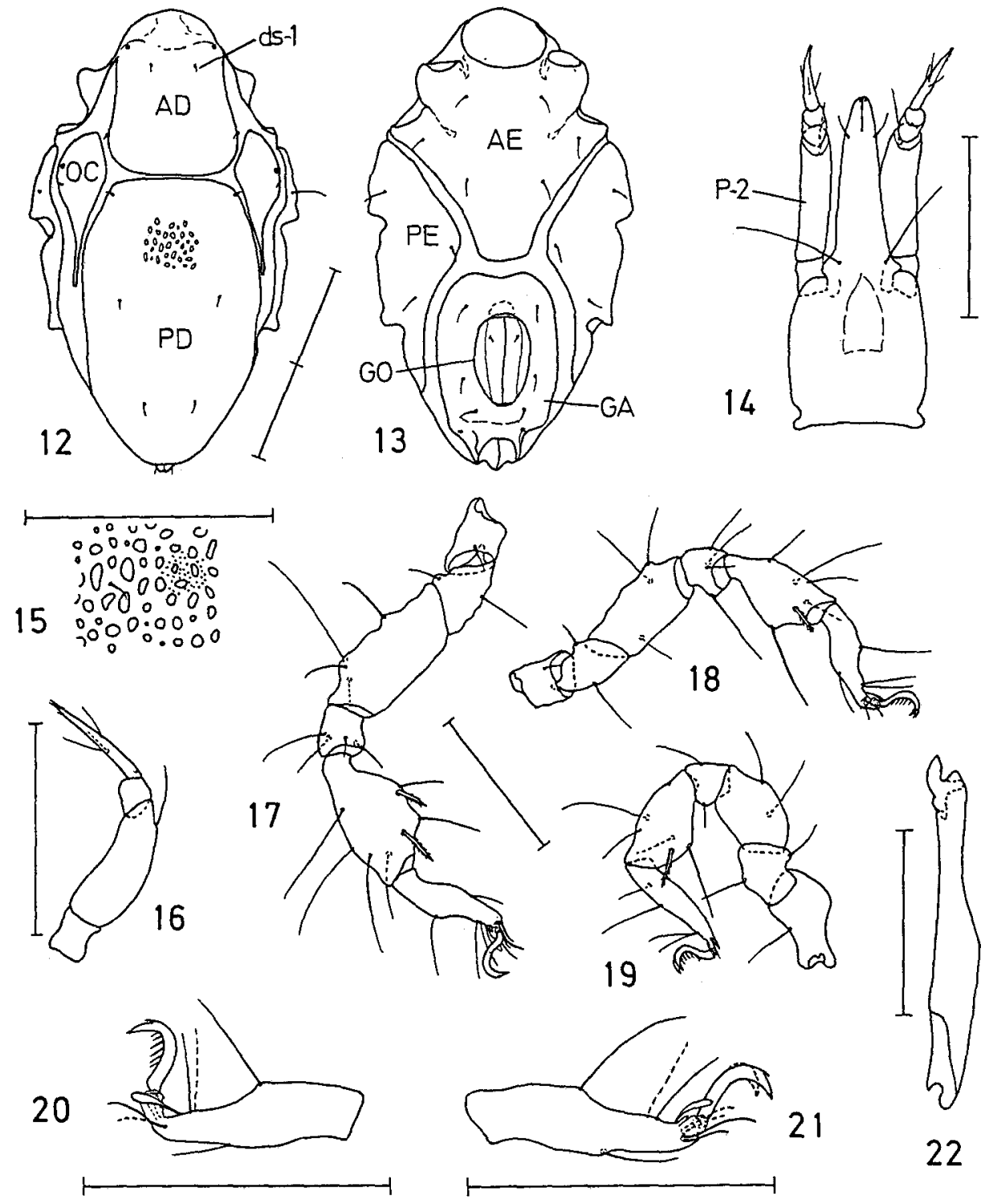

Figs 12-22. Camactognathus borealis n. sp. 12: idiosoma, dorsal view, female; 13: idiosoma, ventral view, female; 14 : gnathosoma, ventral view, female; 15 : detail of posterior dorsal plate, at level of ds4, female; 16: palp, deutonymph; 17: leg I, medial view, female; 18: leg II, medial view, female; 19: leg III, medial view, female; 20: tarsus II, lateral view (medial setae dashed), female; 21: tarsus I, lateral view (medial setae and claw dashed), female; 22: chelicera. (Each scale division represents $50 \mu \mathrm{m}$ ) (AD anterior dorsal plate; AE anterior epimeral plate; ds-1 first pair of dorsal setae; GA genitoanal plate; GO genital opening; OC ocular plate; P-2 2nd palpal segment; PD posterior dorsal plate; PE posterior epimeral plate) 
Leg I stouter than posterior legs; legs shorter than idiosoma. Leg chaetotaxy, from trochanter to tarsus (parambulacral setae and solenidia excluded): Leg I 1, 2,4,4,8,4; leg II $1,2,3,4,6$, 4; leg III $1,2,2,2,5,4$; leg IV 1, 2, 2, 3, 5, 3. Tibia I wide, with two ventromedial bipectinate and two ventrolateral slender bristles (Fig. 17); tibiae II-IV (Figs 18, 19) with one bipectinate ventromedial and one slender ventrolateral bristle. Tarsus I with one ventral and 3 dorsal setae; solenidion large, claviform, famulus rod-like; doubled parambulacral setae on either side of ambulacrum (Fig. 21). Tarsus II with one ventral and 3 dorsal setae, a large claviform solenidion dorsolateral in position, and a pair of single parambulacral setae (Fig. 20). Tarsi III and IV with 4 and 3 dorsal setae respectively, lateral parambulacral setae spine-like, medial one seta-like.

Claws on tarsus I with accessory process. Claws on posterior tarsi with claw comb and few coarse tines.

Male: Not seen.

Deutonymph: Idiosoma length 199-230 $\mu \mathrm{m}$. Dorsal and ventral plates smaller than in adults, with same ornamentation. Posterior OC not caudiform. Genital and anal plate fused (Fig. 23). Primordial genital slit and internal genital acetabula minute. All tibiae with one ventromedial bipectinate and one ventrolateral slender bristle.
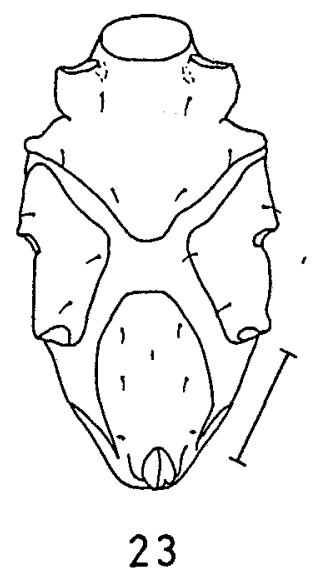

Fig. 23. Camactognathus borealis n. sp., deutonymph, idiosoma, ventral view

Remarks: Camactognathus borealis is very similar to the Mediterranean C. tesselatus (Morselli \& Mari). The most marked difference is the form of the tibiae, more slender in $C$. tesselatus (Fig. 24) than in C. borealis. Moreover, females of $C$. tesselatus have 4 pairs of perigenital setae, whereas $C$. borealis has 3 pairs of setae.

So far, the genus Camactognathus contains three species, viz. C. grossipes Newell, collected in southern Chile (Newell, 1984), C. tesselatus, known from the Mediterranean Sea (Morselli \& Mari, 1982), and C. borealis, taken in the Skagerrak. All species inhabit coarse sediments.

The specimens from the Skagerrak area are fouled with fine debris, trapped between legs and on marginal idiosoma. 


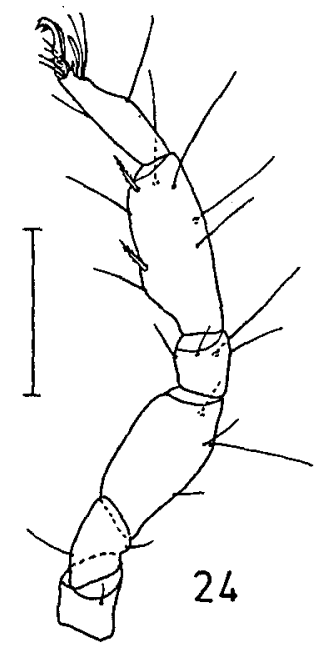

Fig. 24. Camactognathus tesselatus (Morselli \& Mari), female, leg I, medial view

Coloboceras longiusculus Trouessart, 1889

Material: One female, 3 deutonymphs, taken off Bonden at 5 and $25 \mathrm{~m}$ depth.

Diagnosis: Idiosoma length of females $465-500 \mu \mathrm{m}$, of deutonymphs $421-437 \mu \mathrm{m}$. Dorsal and ventral plates finely and evenly punctate; faint reticulation may be present. $\mathrm{AD}$ rounded, almost hexagonal, less than 1.2 longer than, wide. Anterior margin of GA straight. Gnathosoma small, with a globular base. Palps short and slender, 3-segmented. No seta on second palpal segment. Third palpal segment with a single seta in the basal whorl. Legs strong. Telofemora, genua and tibiae posteriorly with lateral and medial lamellae. Tarsus I with numerous ventral eupathidia; posterior tarsi with at least one ventral seta. Solenidion on tarsus I dorsolateral in position, on tarsus II dorsomedial. Claws with large accessory process, posterior claws with strong tines of claw comb.

Coloboceras is likely to be at least temporarily ecto-parasitic in habit.

Species of the genus Coloboceras are recorded from the northeastern Atlantic Ocean and the Mediterranean, $C$. longiusculus from the Atlantic Ocean (Trouessart, 1889; Bartsch, 1973, 1985a; Monniot, 1962).

\section{Copidognathus magnipalpus (Police, 1909)}

Material: One protonymph, with an idiosoma length of $260 \mu \mathrm{m}$, taken off Bonden in $20 \mathrm{~m}$ depth.

Diagnosis: Idiosoma length in Mediterranean population: female 379-413 $\mu \mathrm{m}$, male $365-421 \mu \mathrm{m}$. AD with an oblong anterior and two posterior porose areolae; PD with two longitudinal porose costae; pores fine, arranged in clusters. Outside porose areolae integument coarsely panelled. OC small, with one large and two small corneae. Ventral plates uniformly porose. Gnathosoma short; with three pairs of maxillary setae. Legs stout. Telofemur I with a porose ventral areola. Tibia I ventral with a short bipectinate 
spine and 2 slender, smooth bristles, tibia II with 2 bipectinate and one smooth bristle, tibiae III and IV with a short, bipectinate and a long, slender, smooth bristle. Claws on tarsus I shorter than those on posterior tarsi.

C. magnipalpus is abundant in Mediterranean littoral and sublittoral sediments (Police, 1909; Viets, 1940; Morselli, 1980).

\section{Copidognathus tectirostris Bartsch, 1979}

Material: Approximately 20 specimens, females and protonymphs, taken in 15, 20 and $25 \mathrm{~m}$ depth.

Diagnosis: Idiosoma length of females 304-344 $\mu \mathrm{m}$, of protonymphs $297-317 \mu \mathrm{m}$. AD with costae like an inverted $\mathrm{Y}$, with its anterior edge protruding beyond $\mathrm{AD}$; $\mathrm{PD}$ with 2 longitudinal costae. Costae with rosette pores. Outside costae plates panelled. OC distally slightly caudiform. Ventral plates porose, marginally with rosette pores. Gnathosoma short and stout. Tectum with a dull, long projection. Legs short. Telofemur I panelled and with scattered rosette pores.

C. tectirostris is closely related to $C$. rhodostigma. Differences, recognizable even at low magnification, are the former's large tectum, fainter eye pigment and wider idiosoma. Males have so far not been found in North Atlantic populations of $C$. tectirostris, whereas in populations of $C$. rhodostigma both sexes are present in almost similar numbers.

Copidognathus tectirostris is known from the northeastern Atlantic Ocean and the North Sea (Bartsch 1979, 1985a, b; Green \& MacQuitty, 1987). It also lives in the Mediterranean (unpublished records, material in the author's collection). The Mediterranean females of $C$. tectirostris, with an idiosoma length of $275-310 \mu \mathrm{m}$ (40 specimens measured), are slightly smaller than those in the northern Atlantic.

\section{Actacarus obductus Bartsch, 1977}

Material: Four females; taken at 15, 20 and $25 \mathrm{~m}$ depths, in July 1982.

Diagnosis: Idiosoma length of females 229-254 $\mu \mathrm{m}$ (Skagerrak population), of male $189 \mu \mathrm{m}$ (material from the western Atlantic). All dorsal and ventral plates finely and evenly porose. Setae ds- 2 inserted on margin of $A D, d s-3$ on that of $P D$. OC reduced to a minute triangular sclerite, with a distinct gland pore. PD with 2 adjacent pairs of gland pores in posterior PD. AE and GA separate. Female GA with posterior GO; distance of anterior margin of GA to that of GO twice the latter's length; GA with 4 pairs of perigenital setae; ovipositor long, surpassing GO for more than 1.5 the GO's length (Fig. 25). GO in male smaller than in female; surrounded by 20 perigenital setae (Bartsch, 1977: Figs 2, 3). Rostrum triangular, rather slender, with 2 pairs of maxillary setae inserted close together. Tectum slightly arched. Legs short. I-5 with 4 ventral setae.

The three Actacarus species (A. bacescui Konnerth-Ionescu, A. obductus, A. pygmaeus Schulz) known from northeastern Atlantic Ocean are easily distinguishable, $A$. pygmaeus has the ventral plates AE and GA partly fused (Bartsch, 1976: Fig. 48). The dorsal plates in $A$. bacescui are ornamented with a coarse punctation and the tectum has a small spinelet (Monniot, 1968: Figs 1A, E). In A. obductus, AE and GA are separated, the tectum is slightly rounded. 


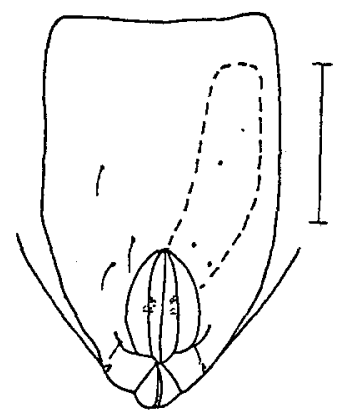

\section{5}

Fig. 25. Actacarus obductus Bartsch, female, genitoanal plate, ventral view.

(Scale division represents $50 \mu \mathrm{m}$ )

Actacarus obductus was first taken from off North Carolina, USA, from $400 \mathrm{~m}$ depth (Bartsch, 1977). A. bacescui is known from the Black Sea, the Mediterranean and from Northern Spain, A. pygmaeus from the Black Sea, Mediterranean, Eastern Atlantic, North Sea and Baltic (cf. Bartsch, 1977; Bartsch \& Schmidt, 1979).

\section{Lohmannella multisetosa Bartsch, 1986}

Material: Thirty-five specimens, females, deutonymphs and protonymphs, taken at 15, 20 and $25 \mathrm{~m}$ depth.

Diagnosis: Mediterranean population: idiosoma length of females 340-427 $\mu \mathrm{m}$. Skagerrak population: idiosoma length of females 390-447 $\mu \mathrm{m}$, deutonymphs 310-366 $\mu \mathrm{m}$, protonymphs $240-253 \mu \mathrm{m}$. Dorsal and ventral plates smooth. Dorsal setae 2,3 and 4 inserted within striated integument. GO in middle of GA. Distance from anterior margin of GA to that of GO less than the latter's length. GA with 50-74 perigenital setae and 3 pairs of large internal genital acetabula. Gnathosoma length $0.61-0.66$ of idiosoma length. P-1 wide. P-2 with convex ventral margin. Legs distinctly shorter than idiosoma. Tibia I with three pairs of bipectinate bristles. Tarsi I, II and IV each with one, tarsus III with two ventral bipectinate bristles respectively. Legs usually fouled. Males have as yet not been found.

Beside L. multisetosa, L. falcata (Hodge) is also frequently found in the North Sea and Skagerrak area. Even at low magnification, $L$. multisetosa is distinguishable from $L$. falcata by the former's fouling of the legs, distinctly wider P-1 (at dorsal view), large GO and large genital acetabula. Both species live, side by side, in sediments off the island Bonden.

Lohmannella multisetosa was first recorded from the Mediterranean (Bartsch, 1986); where it was common in sediment samples taken at 11-45 $\mathrm{m}$ depth. A single specimen has been found in the English Channel (unpublished records; material in the author's collection). 
Acknowledgements. I am very much indebted to Dr. Cl. Poizat, Marseilles, and Dr. H. Kunz, Saarbrücken, for providing the halacarid material, and Dr. I. Morselli, Modena, for the loan of Camactognathus tesselatus.

\section{LITERATURE CITED}

Bartsch, I., 1973. Halacaridae (Acari) von der Josephinebank und der Großen Meteorbank aus dem östlichen Nordatlantik. II. Die Halacaridae aus den Bodengreiferproben. - Meteor Forsch. Ergebn. (D) 15, 51-78.

Bartsch, I., 1976. Beitrag zur Halacariden-Fauna (Halacaridae, Acari) der Bretagneküste. Beschreibung von fünf Arten aus dem Sandlückensystem. - Acarologia 17, 652-667.

Bartsch, I., 1977. Eine neue Actacarus-Art (Acari, Halacaridae) aus dem Bathyal vor der Küste von North Carolina, USA. - Zool. Scr. 6, 323-326.

Bartsch, I., 1979. Ergänzungen zur Copidognathus-Fauna (Halacaridae, Acari) der Bretagne-Küiste. - Acarologia 20, 217-234.

Bartsch, I., 1985a. Halacaridae (Acari) from the Strangford Narrows and the Irish Sea. - Proc. R. Ir. Acad. (B) 85, 21-35.

Bartsch, I., 1985b. Notes on the Halacaridae (Acari) of Yorkshire. - Naturalist 110, 41-48.

Bartsch, I., 1986. Lohmannellinae (Halacaroidea, Acari) aus dem Mittelmeer. - Entomol. Mitt. zool. Mus. Hamburg $8,231-244$.

Bartsch, I. \& Schmidt, P., 1979. Zur Verbreitung und Ökologie einiger Halacaridae (Acari) in Sandstränden der Ostsee (Kieler Bucht), der Nordsee (Sylt) und des Europäischen Nordmeeres. Mikrofauna Meeresboden 74, 1-37.

Green, J.' \& MacQuitty, M., 1987. Halacarid mites. Brill, Leiden, 178 pp. (Synopses of the British Fauna. 36.)

Morselli, I., 1980. Su tre Acari Prostigmati di acque salmastre dell'alto Adriatico. - Atti Soc. tosc. Sci. nat., Mem. (B) 87, 181-195.

Morselli, I. \& Mari, M., 1982. Alacaridi (Acari, Prostigmata) di fondi sabbiosi della costa ionica del salento. - Atti Soc. tosc. Sci. nat., Mem. (B) 88, 229-247.

Monniot, F., 1962. Description d'une nouvelle espèce d'acariens, Halacaridae, Coloboceras drachi, récoltée en Méditerranée. - Bull. Soc. zool. Fr. 87, 491-498.

Monniot, F., 1967. Deux halacariens endopsammiques: Halacarus anomalus Trouessart et Halacarus marcandrei n.sp. - Cah. Biol. mar. 8, 89-98.

Monniot, F., 1968. Le genre Actacarus (Halacaridae). - Acarologia 10, 6-12.

Newell, I. M., 1984. Antarctic Halacaroidea. - Antarct. Res. Ser. 40, 1-284.

Police, G., 1909. Alcune nuove specie di Halacaridae del Golfo di Napoli. - Archo. zool. ital. 3, $409-443$.

Sellnick, M., 1949. Milben von der Küste Schwedens. - Entomol. Tidskr. 70, 123-135.

Trouessart, E., 1889. Revue synoptique de la famille des Halacaridae. - Bull. scient. Fr. Belg. (sér. 3) $20,225-251$.

Viets, K., 1940. Meeresmilben aus der Adria (Halacaridae und Hydrachnellae, Acari). - Arch. Naturgesch. 9, 1-135. 